\title{
The relationship between ownership concentration and performance in Czech Republic
}

\author{
Ondřej Machek \\ Faculty of Business Administration, University of Economics, Prague \\ Crech Republic \\ ondrej.machek@vse.cr.
}

\author{
Aleš Kubíček \\ Faculty of Business Administration, University of Economics, Prague \\ Crech Republic \\ ales.kubicek@vse.cz.
}

\begin{abstract}
Theory suggests that low ownership concentration is associated with agency costs and highly concentrated ownership structures induce controlling owners to pursue private benefits. Both situations are likely to be associated with negative effects on corporate performance. A number of studies have tested the relationship between ownership concentration and performance empirically, failing to provide any consistent results. While most research has been devoted to study cases of developed countries, the literature on Central and Eastern European countries does not provide better perspectives. The goal of this paper is to explore the relationship between ownership concentration and performance in the case of Czech firms. The research sample contains 34,284 companies and their financial data in the period of 2007-2015. Using linear regression analysis, an inverted U-shaped relationship was found between the Herfindahl index and profitability while controlling for firm size, capital structure, and industry affiliation. No evidence of a linear relationship. Based on one of the largest samples of firms, it is suggested that more concentrated ownership reduces the principal-agent problem and supports performance, but only to a certain extent, where the potential principal-principal problem can still prevail. Moreover, performance is maximized when there is a controlling owner. The findings can be used by policy makers when designing ownership structures.
\end{abstract}

Keywords: Ownership concentration, performance, Herfindahl index, profitability, Czech Republic.

JEL Classification: M41, L25 


\section{INTRODUCTION}

The relationship between ownership structures and firm performance has received considerable academic attention over the past decades. One of the major topics of research, especially in highly developed countries, has been the question of whether the number of shareholders and their relative power influence performance. The relative amount of stock owned by individual shareholders is often measured by ownership concentration. A very concentrated ownership can improve monitoring and reduce agency costs, but on the other hand, large shareholders can expropriate smaller investors or harm performance by monitoring managers in an excessive manner. Literature presents the conflicting results and most research has been carried out in developed economies thus somehow leaving other, less developed countries, outside the study field. At the same time, conditions in the countries with weaker legal protection, such as the post-socialist European countries, are different from those in Anglo-Saxon countries and they certainly deserve further academic attention.

Recently, a study of approximately 5,000 Czech firms with data for the period of 2010 to 2012 has found a weak negative effect of ownership concentration on corporate financial performance (Konečný \& Ćástek, 2016). As those authors note, their results did not reveal whether there is a monotonous or concave relationship. A longer time frame and perhaps a more comprehensive sample of firms would offer a better insight into the true relationship between ownership concentration and performance.

The aim of this paper is to fill the gap and further explore the nature of the impact of ownership concentration on performance in Czech Republic. The remainder of this article is organized as follows. First, there is a review of relevant literature and a formulation of the research hypothesis. Then, the data and the methods used are presented. Subsequently, the results are reported and discussed. Finally, concluding remarks are presented.

\section{LITERATURE REVIEW}

The fundamental theories of corporate governance are based on the principal-agent problem (Berle \& Means, 1932) which is sometimes referred to as an agency problem of Type I. Due to information asymmetry and limited rationality of people, managers (agents) may be tempted to act in their own interest rather than follow the interests of the owners (principals). To prevent this opportunistic behavior of managers, owners often employ monitoring mechanisms, which are associated with agency costs that are borne by the owners in an effort to align the interests of both parties to maximize shareholder value (Jensen \& Meckling, 1976).

When ownership is concentrated in the hands of a few shareholders, the incentives of those shareholders to control and monitor the management may become stronger. A higher ownership concentration may result in a structure with a controlling owner who can become significantly involved in company management, actively monitor management and reduce management opportunism (Burkart et al., 1997). However, past research suggests that although the principal-agent problem is minimized by the presence of the controlling owner, the controlling owner himself may become another source of corporate governance issues. Since a high ownership concentration prevails in most countries of the world, attention has been devoted to the relationships among various owners and to the potential principal-principal problem (Young et al., 2008) which is also known as the agency problem of Type II. If the controlling owner starts to prefer his own self-interests over the collective interests, he may attempt to take advantage of his control at the expense of minority owners and expropriate the wealth of those minority owners.

The relationship between ownership concentration and performance is influenced by two relatively conflicting problems. On the one hand, low levels of ownership concentration are associated with agency 
costs as managers must be monitored which negatively affects performance. On the other hand, highly concentrated ownership structures may induce controlling owners to pursue private benefits which also have a negative effect on performance. It is therefore no wonder that a number of authors found evidence of a nonlinear relationship between ownership concentration and performance. However, the exact nature of this relationship remains unclear and the literature offers conflicting findings.

Further, a number of authors (e.g. Short et al., 1999; Gugler et al., 2008) find that increasing ownership concentration first reduces agency costs, but subsequently, rent-seeking large investors offset positive effects. Eventually, the interests of owners and managers become better aligned, which increases performance. A relationship of this type is known as an "up-down-up" relationship.

Other authors (e.g. McConnell \& Servaes, 1990; Thomsen \& Pedersen, 2000; Arosa et al., 2010) found evidence of an inverted U-shaped relationship between ownership concentration and performance. The reduction of agency costs due to the alignment of interests of owners and managers results in better performance, but at a certain point, advantages are mitigated by exploitation of private benefits by controlling shareholders. Very high levels of ownership concentration can allow a controlling shareholder to dominate the decision-making process of a corporation, which could result in the expropriation of wealth from minority shareholders (Caixe \& Krauter, 2013).

Due to the existence of a large number of studies exploring the relationship between ownership concentration and performance, researchers employed meta-analytical techniques to systematize their findings. In a meta-analysis of 33 studies examining the effects of ownership structure on company performance, Sánchez-Ballesta and García-Meca (2007) conclude that the overall relationship is insignificant. However, according to their findings, in continental countries characterized by agency conflict between blockholders and minority owners, ownership concentration has a higher effect on performance than in Anglo-Saxon countries. Similar findings have been presented by Heugens et al. (2009) in their meta-analysis of 65 studies which examines the relationship in Asian countries. The authors found a small but significant positive overall effect which is observable mainly in countries with weaker legal protection. However, a more recent meta-analysis by Wang and Shailer (2015) found that ownership concentration was negatively related to firm performance across listed corporations in 18 emerging markets. Hence, even existing meta-analyses provide conflicting results.

One of the pioneering works exploring the relationship between ownership concentration and performance in Central and Eastern European (CEE) countries was presented by Claessens and Djankov (1999) who found that the more concentrated the ownership, the higher the firm profitability and labor productivity. However, the study was based on Czech data in the period of 1992 to 1997 which was affected by the transformation from centrally-planned economy to a market economy economy. Later studies found evidence of a nonlinear relationship, such as that of Dzanic (2012) who argue that the existence of a blockholder owning more than $30 \%$ of the equity stake negatively affected Tobin's q of Croatian listed companies. However, other authors found no significant influence of ownership control on productivity in CEE countries such as Slovenia (Damijan et al., 2004) or company performance of Hungarian (Earle et al., 2005), Czech (Nowak \& Kubíček, 2012) and Polish companies (Grosfeld \& Hashi, 2007). Balsmeier and Czarnitzki (2017) examine the relationship between ownership concentration and firm performance in the context of institutional environments in 28 Central and Eastern European transition countries and found an inverted U-shaped relation for non-EU and less developed countries.

The most relevant study is the paper of Konečný and Částek (2016) who, using a sample of more than 5,000 Czech firms with data in the period of 2010 to 2012, found a weak negative effect of ownership concentration, as measured by the Herfindahl index, on return on assets. However, the true nature of the relationship - whether it is monotonous or concave - remains unknown. 
To sum up, literature from CEE countries presents inconsistent results. Taking into account all the above-mentioned arguments, it is hypothesized that:

H1: In Czech firms, there is an inverted U-shaped relationship between ownership concentration and performance.

\section{DATA AND METHODS}

The basic data source was the Amadeus database of Bureau van Dijk. All Czech firms with available long-term data from 2007-2015 (nine years) were selected. This period includes the year before the arrival of the global financial crisis and several years after it. To take into account year-to-year variations, we used mean values in the period of 2007 to 2015 for all variables which are described below. Subsequently, all firms with incomplete data were eliminated.

The total sample contains 34,284 firms. To compare the sample characteristics with those of the population, a structural analysis of the sample based on NACE industry classification and number of employees is presented. Tables 1 and 2 illustrate the differences based on data from Czech Statistical Office and Eurostat.

Table 1

Sample characteristics - number of employees (by 2015)

\begin{tabular}{|c|c|c|}
\hline Number of employees & Sample [\%] & Population [\%] \\
\hline 1 to 5 & 75.88 & 70.28 \\
\hline 6 to 9 & 14.66 & 9.99 \\
\hline 10 to 49 & 28.80 & 15.08 \\
\hline 50 to 99 & 4.36 & 2.48 \\
\hline 100 to 249 & 2.29 & 1.39 \\
\hline 250 to 499 & 0.52 & 0.45 \\
\hline 500 or more & 0.23 & 0.35 \\
\hline
\end{tabular}

Source: Own calculations, population data collected from ČSÚ (2017).

Table 2

Sample characteristics - industry affiliation (by 2015)

\begin{tabular}{|c|c|c|}
\hline NACE classification & Sample $[\%]$ & Population [\%] \\
\hline A. Agriculture, forestry and fishing & 2.61 & 2.91 \\
\hline B. - E. Industry total & 18.14 & 21.86 \\
\hline G. Wholesale and retail trade; repair of motor vehicles and motorcycles & 24.30 & 28.52 \\
\hline H. Transportation and storage & 3.87 & 4.31 \\
\hline I. Accommodation and food service activities & 5.84 & 2.47 \\
\hline J. Information and communication & 3.53 & 4.42 \\
\hline L. Real estate activities & 4.72 & 4.28 \\
\hline M. Professional, scientific and technical activities & 17.00 & 14.27 \\
\hline N. Administrative and support service activities & 3.06 & 3.53 \\
\hline A. Agriculture, forestry and fishing & 2.61 & 2.91 \\
\hline B. - E. Industry total & 18.14 & 21.86 \\
\hline
\end{tabular}

Source: Own calculations, population data collected from ČSÚ (2017).

Obviously, there are minor differences in terms of industry affiliations and sizes. It should be noted that the data on employment have to be treated carefully since the "number of employees" in the Amadeus database corresponds to centers of intervals representing the size of the company in terms of employment. The sample contains a larger proportion of firms operating in NACE sections I and M and a lower proportion of firms operating in sections B-E and G. However, no population group is much 
under- or overrepresented; hence, the sample of firms is considered to be fairly representative of the population of all Czech firms.

\subsection{Dependent variables}

To obtain robust results, the performance of firms was measured using two correlated, but different indicators:

- Return on assets (earnings before interests and taxes over total assets) further denoted by ROA.

- Return on equity (net income over equity) further denoted by ROE.

- Return on assets, as well as return on equity, belongs to the most frequently used measures of performance in past comparative studies (Machek et al., 2013).

\subsection{Independent variables}

In this paper, ownership concentration is measured using the Herfindahl index, which is usually calculated according to the following formula:

$$
H=\sum_{i} s_{i}^{2}
$$

$H$ is the sum of squares of ownership shares (denoted by $s_{i}$ ) across all shareholders in a firm. Highly concentrated ownership structures will have $H$ close to one, while dispersed ownership will be characterized by low values of $H$. Since we hypothesize that concentration has an inverted U-shaped relationship with performance, we introduce both the linear and quadratic terms to the regression equation. The variable is hereinafter referred to as Herfindahl.

In order to include size and scale effects, firm size (as measured by the natural logarithm of total assets) is controlled for. The aim was to control for age of firms (maturation effects), but because of a strong correlation with firm size, this variable was omitted to avoid multicollinearity issues. To take into account capital structure effects, Gearing (debt over equity), which is a measure directly convertible to the debt ratio (debt-to-assets), is also controlled for. Besides these variables, industry affiliation (nine dummy variables representing broad NACE categories) is comtrolled for because market conditions and performance drivers vary across industries (see e.g. Kaupelyte \& Mscichauskas, 2016, p. 83).

To test the hypothesis, linear regression analysis in SPSS was used. Since the variance of the residuals is not constant, a regression model with heteroscedasticity-consistent standard errors, with a procedure implemented by Hayes and Cai (2007), had to be used.

\section{RESULTS}

Table 3 presents descriptive statistics for the main variables and Figure 1 displays their histograms. As the position of medians suggests, return on equity, return on assets and firm size are skewed to the right. The average return on assets is $7.673 \%$, while the average return on equity is $15.310 \%$.

The Herfindahl index is a highly discrete variable and for most firms its value is equal to one due to sole proprietorship. The gearing mean value is 0.236 , which corresponds to the debt ratio of $19 \%$. Many firms in the sample have no liabilities and, obviously, the number of firms is decreasing with an increasing debt-to-equity ratio, as can be seen in Figure 1. 


\section{Table 3}

Descriptive statistics

\begin{tabular}{|c|c|c|c|}
\hline & Mean & Std. dev. & Median \\
\hline ROE & 15.310 & 27.610 & 13.598 \\
\hline ROA & 7.673 & 9.817 & 5.480 \\
\hline Herfindahl & 0.730 & 0.285 & 0.820 \\
\hline Firm size & 9.150 & 1.405 & 9.055 \\
\hline Gearing & 0.236 & 0.249 & 0.150 \\
\hline
\end{tabular}

Source: Own calculations based on the Amadeus database

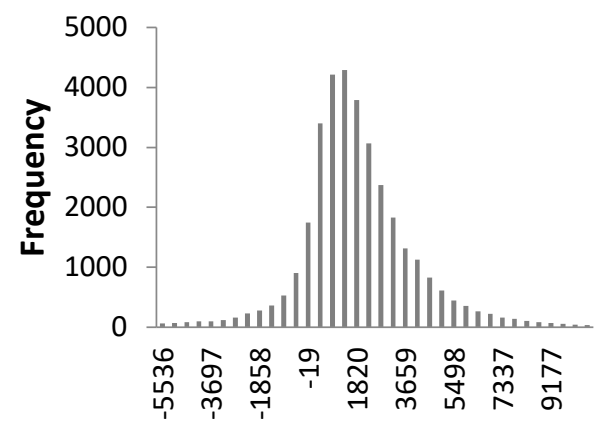

Return on equity

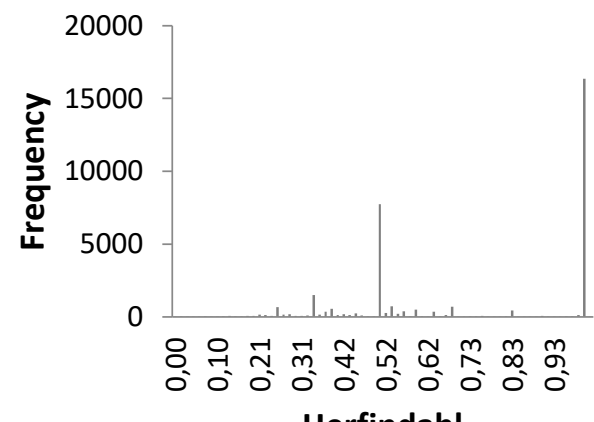

Herfindahl

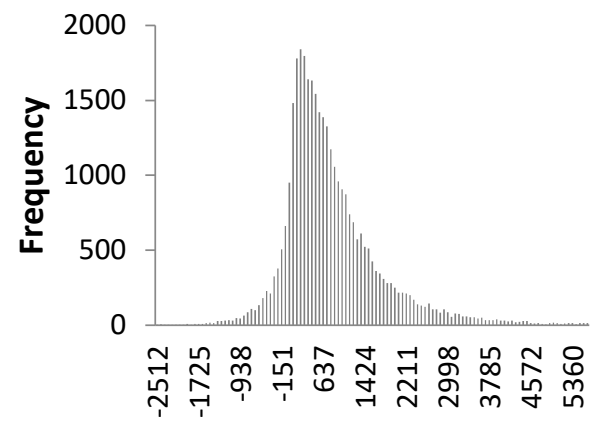

Return on assets

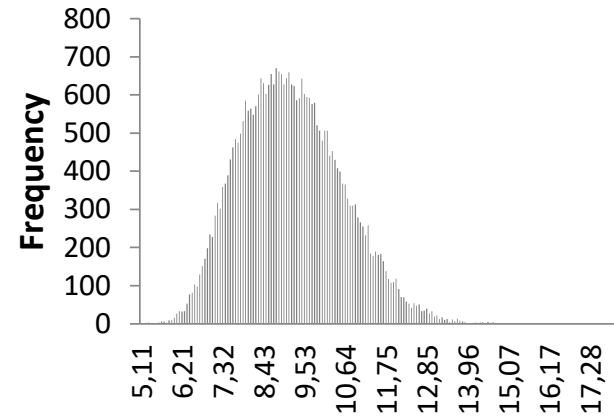

Size

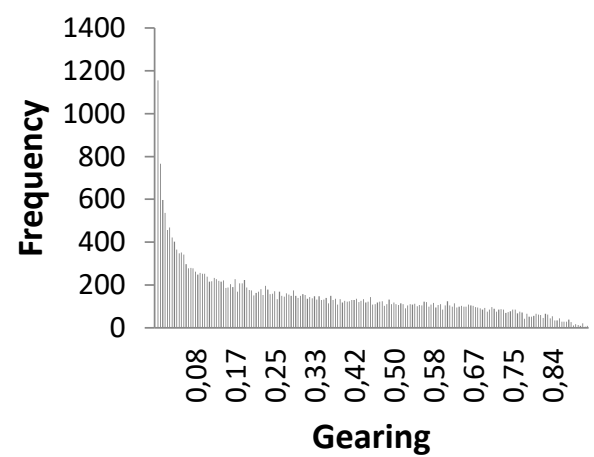

Figure 1. Histograms of the key variables

Source: Own calculations based on the Amadeus database 
In Table 4, the bivariate Pearson correlation coefficients, which measure linear associations between two variables, are reported. The two dependent variables, ROE and ROA, are significantly correlated. There is a strong negative correlation between ownership concentration and firm size (in other words, larger firms tend to have a lower ownership concentration, which implies a more dispersed ownership).

Table 4

Correlation table

\begin{tabular}{|c|c|c|c|c|c|}
\hline & ROE & ROA & Herfindahl & Firm size & Gearing \\
\hline ROE & 1 & & & & \\
\hline ROA & $0.586^{* *}$ & 1 & & & \\
\hline Herfindahl & 0.001 & -0.007 & 1 & & \\
\hline Firm size & -0.003 & $-0.82^{* *}$ & $-0.73^{* *}$ & 1 & 1 \\
\hline Gearing & $-0.073^{* *}$ & $-0.285^{* *}$ & $-0.027^{* *}$ & $0.118^{* *}$ & \\
\hline
\end{tabular}

** - significant at the 0.01 level.

Source: Own calculations based on the Amadeus database

Also, there is a weak but significant positive correlation between size and gearing (larger firms tend to use more debt than smaller firms) and a weak negative correlation between ownership concentration and gearing (firms which use more debt tend to have a lower ownership concentration). ROA is significantly and negatively correlated with firm size and gearing, while ROE is negatively correlated only with gearing.

The correlation between ownership concentration (Herfindahl) and profitability is very low and statistically insignificant. This supports the hypothesis that there is no linear relationship between ownership concentration and profitability and suggests that there may be a nonlinear relationship between these variables. To verify the previous statement, two regression models were estimated: a linear model and a quadratic model (U-shaped relationship).

Table 5 presents the regression results where both ROA and ROE as independent variables. The first part presents the results of the linear model; the second part displays the results of the quadratic model. According to F-tests, all regressions are statistically significant. While the regressions yielded low Rsquared values and left some variation of the data unexplained, they revealed important relationships between the variables used in the analysis.

Table 5

Regression results

\begin{tabular}{|l|c|c|c|c|}
\hline \multirow{2}{*}{ N $=34284$} & \multicolumn{2}{c|}{ Linear } & \multicolumn{2}{c|}{ Quadratic } \\
\cline { 2 - 5 } & \multicolumn{2}{|c|}{ Dependent variable } & \multicolumn{2}{c|}{ Dependent variable } \\
\hline \multicolumn{1}{|c|}{ Predictors } & ROA & ROE & ROA & ROE \\
\hline Intercept & $905.810^{* *}$ & $785.213^{* *}$ & $807.605^{* *}$ & $495.395^{*}$ \\
\hline Herfindahl & -12.077 & 21.815 & $306.059^{* *}$ & $960.689^{* *}$ \\
\hline Herfindahl squared & omitted & omitted & $-228.268^{* *}$ & $-673.656^{* *}$ \\
\hline Size (ln assets) & $-9.117^{* *}$ & $51.42^{* *}$ & $-8.394^{*}$ & $53.559^{* *}$ \\
\hline Gearing & $-1038.118^{* *}$ & $-713.407^{* *}$ & $-1039.666^{* *}$ & $-737.975^{* *}$ \\
\hline \multicolumn{4}{|c|}{ Regression statistics } \\
\hline F-value & $407.400^{* *}$ & $44.6522^{* *}$ & $376.452^{* *}$ & $41.92^{* *}$ \\
\hline $\mathrm{R}^{2}$ & 0.136 & 0.020 & 0.1360 & 0.020 \\
\hline
\end{tabular}

For clarity, industry dummies are not displayed.

* - significant at the 0.05 level, ** - significant at the 0.01 level

Source: Own calculations based on the Amadeus database. 
In both models, the level of debt negatively affects profitability (employing more debt is associated with greater interest costs). Size significantly and negatively affects return on assets, but it affects positively return on equity.

With respect to ownership concentration, the results provide strong support for the hypothesis H1. The quadratic term is significant at the 0.01 level and negative, which suggests that there is an inverted Ushaped relationship between ownership concentration and performance - both for ROA and for ROE.

Assuming that the relationship between profitability and ownership concentration is a quadratic expression with the estimated coefficients, the relative maximum of the quadratic function may be found by putting the first derivative or ROA (ROE) with respect to Herfindahl to zero. Ceteris paribus, the maximum performance is achieved at about $67 \%$ of ownership concentration (as measured by the Herfindahl index) for return on assets, and at about $71 \%$ for return on equity.

\section{DISCUSSION}

The findings support the research hypothesis. As expected, it was found that ownership concentration has an inverted U-shaped relationship with performance, and it was also found that there is no evidence of a linear relationship between ownership concentration and performance. The results extend earlier research findings (McConnell \& Servaes, 1990; Thomsen \& Pedersen, 2000; Arosa et al., 2010) to the Czech environment. Compared to the most relevant study (Konečný \& Částek, 2016), a much larger sample of Czech firms and a longer time period that incorporated both the year before the global financial crisis, the crisis, and its aftermath, were used.

Consistent with prior findings, the results suggest that when ownership concentration increases, agency costs are reduced due to the alignment of interests of owners and managers. However, at a certain point, performance starts decreasing and negative effects of ownership concentration prevail. According to the results of the present study for Czech firms, the turning point is $67 \%$ for return on assets and $71 \%$ for return on equity.

In other words, the results suggest that companies with a controlling owner are more profitable than firms with dispersed ownership. This can be attributed by the mitigation of the principal-agent conflict, where the controlling owner can effectively control and monitor management and reduce management opportunism (Burkart et al., 1997).

However, this study also has limitations. Only Czech firms were included in the sample. A "survival bias" can occur, meaning that only firms which "survived" the period of 2007 to 2015 are included in the sample, thus introducing a bias to the sample. Moreover, there was no control for potential endogeneity of ownership structure which would imply reverse causality. In other words, ownership structure may reflect decisions of shareholders and capital market and these decisions shape ownership structure based on company performance and share price (Demsetz \& Villalonga, 2001). Rare studies which controlled for endogeneity tend to suggest a positive relationship between ownership concentration and performance (Cabeza-Garcia \& Gomez-Anson, 2011).

\section{CONCLUSION}

The relationship between ownership concentration and performance has been the subject of many studies in the past, especially in the developed countries. However, literature has been relatively silent on this topic in Central European countries. Consistent with multiple authors, the results of the present study suggest that there exists an inverted U-shaped relationship between ownership concentration and financial performance. This paper extends the recent findings of Konečný and Částek (2016) by using a more 
comprehensive sample of firms, by focusing on a longer time period of 9 years and by using two measures of financial performance.

However, further research is warranted. An international comparison would shed more light on the nature of the relationship between ownership concentration and performance, including the location of the "turning point", i.e. the optimal ownership concentration is maximized. Literature is still not consistent on that topic. Also, a more detailed analysis should include qualitative variables, such as the characteristics of shareholders, as well as the presence of insider (managerial) ownership, institutional or corporate ownership, or family ownership, among others. These complex variables can enter into the model either as independent variables or moderating factors. Finally, the reasons "why" certain aspects occur are of great importance thus implying the need for qualitative research.

\section{ACKNOWLEDGEMENT}

The authors are thankful to the Czech Science Foundation which supported the project entitled "Privately-held Firms with Multiple Owners: The Role of Family and Responsible Ownership" (registration no.: GA17-10948S). We would also like to thank the anonymous reviewers for their comments that allowed us to improve the quality of the paper.

\section{REFERENCES}

Arosa, B., Iturralde, T., \& Maseda, A. (2010). Ownership structure and firm performance in non-listed firms: Evidence from Spain. Journal of Family Business Strategy, 1(2), 88-96. doi:10.1016/j.jfbs.2010.03.001

Balsmeier, B., \& Czarnitzki, D. (2017). Ownership concentration, institutional development and firm performance in Central and Eastern Europe. Managerial and Decision Economics, 38(2), 178-192. doi:10.1002/mde.2751

Berle, A., \& Means, G. (1932). The modern corporate and private property. New York, NY: McMillian.

Burkart, M., Gromb, D., \& Panunzi, F. (1997). Large shareholders, monitoring, and the value of the firm. The Quarterly Journal of Economics, 112(3), 693-728. doi:10.1162/003355397555325

Cabeza-García, L., \& Gómez-Ansón, S. (2011). Post-privatisation ownership concentration: Determinants and influence on firm efficiency. Journal of Comparative Economics, 39(3), 412-430. doi: 10.1016/j.jce.2011.02.002

Caixe, D. F., \& Krauter, E. (2013). The influence of the ownership and control structure on corporate market value in Brazil. Revista Contabilidade \& Finanças, 24(62), 142-153. doi: 10.1590/S1519-70772013000200005

Claessens, S., \& Djankov, S. (1999). Ownership concentration and corporate performance in the Czech Republic. Journal of Comparative Economics, 27(3), 498-513.

ČSÚ (2017). Businesses by size of business (number of employees). Czech Statistical Office. Retrieved August 21, 2017 from https://vdb.czso.cz/vdbvo2/faces/en/index.jsf?page=statistiky\&katalog $=30831$

Damijan, J., Gregoric, A., \& Prasnikar, J. (2004). Ownership Concentration and Firm Performance in Slovenia. LICOS Centre for Transition Economics, Discussion Paper 142/2004.

Demsetz, H., \& Villalonga, B. (2001). Ownership structure and corporate performance. Journal of Corporate Finance, 7(3), 209-233. doi: 10.1016/S0929-1199(01)00020-7

Džanić, A. (2012). Concentration of ownership and corporate performance: evidence from the Zagreb Stock Exchange. Financial Theory and Practice, 36(1), 29-52.

Earle, J. S., Kucsera, C., \& Telegdy, A. (2005). Ownership concentration and corporate performance on the Budapest stock exchange: Do too many cooks spoil the goulash? Corporate Governance: An International Review, 13(2), 254264. doi: 10.1111/j.1467-8683.2005.00420.x

Eurostat (2017). Structural business statistics global business activities. Eurostat. Retrieved August 20, 2017 from http:/ / ec.europa.eu/eurostat/web/structural-business-statistics/data/database.

Grosfeld, I., \& Hashi, I. (2007). Changes in ownership concentration in mass privatised firms: Evidence from Poland and the Czech Republic. Corporate Governance: An International Review, 15(4), 520-534. doi:10.1111/j.14678683.2007.00585.x 
Gugler, K., Mueller, D. C., \& Yurtoglu, B. B. (2008). Insider ownership, ownership concentration and investment performance: An international comparison. Journal of Corporate Finance, 14(5), 688-705. doi:10.1016/j.jcorpfin.2008.09.007

Hayes, A. F., \& Cai, L. (2007). Using heteroscedasticity-consistent standard error estimators in OLS regression: An introduction and software implementation. Behavior Research Methods, 39, 709-722. doi:10.3758/BF03192961

Heugens, P. P., Van Essen, M., \& van Oosterhout, J. H. (2009). Meta-analyzing ownership concentration and firm performance in Asia: Towards a more fine-grained understanding. Asia Pacific Journal of Management, 26(3), 481-512. doi: 10.1007/s10490-008-9109-0

Jensen, M. C., \& Meckling, W. H. (1976). Theory of the firm: Managerial behavior, agency costs and ownership structure. Journal of Financial Economics, 3(4), 305-360. doi:10.1016/0304-405X(76)90026-X

Kaupelyte, D., \& Mscichauskas, D. (2016). Analysis of Factors Influencing Financial Leverage in Lithuanian Listed Companies. Central European Business Review, 5(2), 74-86. doi: 10.18267/j.cebr.153.

Konečný, L., \& Částek, O. (2016). The Effect of Ownership Structure on Corporate Financial Performance in the Czech Republic. Ekonomický časopis, 64(5), 477-498.

Machek, O., Brabec, M., \& Hnilica, J. (2013). Measuring performance gaps between family and non-family businesses: A meta-analysis of existing evidence. International Academic Research Journal of Business and Management, 2(3), 17-30.

McConnell, J. J., \& Servaes, H. (1990). Additional evidence on equity ownership and corporate value. Journal of Financial Economics, 27(2), 595-612. doi: 10.1016/0304-405X(90)90069-C

Nowak, O. \& Kubíček, A. (2012). Corporate governance and company performance: evidence from the Czech Republic. Advances in Economics, Risk Management, Political \& Law Science, 235-240.

Sánchez-Ballesta, J. P., \& García-Meca, E. (2007). A meta-analytic vision of the effect of ownership structure on firm performance. Corporate Governance: An International Review, 15(5), 879-892. doi:10.1111/j.14678683.2007.00604.x

Short, H., \& Keasey, K. (1999). Managerial Ownership and the Performance of Firms: Evidence from the UK. Journal of Corporate Finance, 5(1), 79-101. doi: 10.1016/S0929-1199(98)00016-9

Thomsen, S., \& Pedersen, T. (2000). Ownership structure and economic performance in the largest European companies. Strategic Management Journal, 21(6), 689-705. doi:10.1002/(SICI)1097-0266(200006)21:6<689::AIDSMJ115>3.0.CO;2-Y

Young, M. N., Peng, M. W., Ahlstrom, D., Bruton, G. D., \& Jiang, Y. (2008). Corporate governance in emerging economies: A review of the principal-principal perspective. Journal of Management Studies, 45(1), 196-220. doi:10.1111/j.1467-6486.2007.00752.x

Wang, K., \& Shailer, G. (2015). Ownership concentration and firm performance in emerging markets: A metaanalysis. Journal of Economic Surveys, 29(2), 199-229. doi: 10.1111/joes.12048 